\title{
ANALISIS BAHAN AJAR SENYAWA KARBON BERDASARKAN KRITERIA KETERHUBUNGAN REPRESENTASI KIMIA
}

\author{
Neneng Windayani ${ }^{*}$, Ika Hasanah ${ }^{1}$, dan Imelda Helsy ${ }^{1}$ \\ ${ }^{1}$ Pendidikan Kimia Fakultas Tarbiyah dan Keguruan Universitas Islam Negeri Sunan \\ Gunung Djati Bandung, Jalan A. H. Nasution No. 105 Cibiru Bandung 40614 Indonesia \\ *E-mail: nenengwinda.ftk@uinsgd.ac.id
}

\begin{abstract}
ABSTRAK
Penelitian ini bertujuan untuk menganalisis konten teks konsep senyawa karbon berdasarkan struktur makro dan representasi kimia gambar. Dilakukan terhadap buku teks kimia SMA/MA menggunakan kriteria struktur makro Siregar dan kriteria keterhubungan representasi kimia GKitzia. Hasil analisis konten pada buku A dan buku $\mathrm{B}$ menunjukkan penyajian konten dan cakupannya tidak seluas dan sedalam konten pada buku teks standar. Namun konsep-konsep yang disajikan sudah sesuai dengan kurikulum. Berdasarkan struktur makro, alur penyajian konten pada buku teks standar sebagian besar menggunakan alur induktif, sedangkan pada buku A dan buku B menggunakan alur deduktif. Representasi teks dari ketiga buku lebih dominan simbolik. Hasil analisis representasi gambar yang disajikan pada buku teks standar sudah memenuhi kriteria, namun pada buku A dan buku B belum memenuhi kriteria standar. Dari ketiga buku, lebih banyak menampilkan gambar dengan representasi simbolik. Makna yang terkandung dalam representasi dari ketiga buku sebagian besar bersifat implisit. Keterhubungan representasi dari buku teks standar dan buku B hampir sepenuhnya terkait dan terhubung dengan teks, sedangkan pada buku A hampir sepenuhnya terkait tetapi tidak terhubung. Ketiga buku lebih dominan tidak memiliki keterangan atau caption dari setiap gambar. Hanya buku standar yang memiliki representasi multipel, dengan keterhubungan yang ditunjukan dengan jelas tetapi kurang terhubung.
\end{abstract}

Kata kunci: buku teks, senyawa karbon, kriteria keterhubungan representasi kimia.

\begin{abstract}
The study aims to analyze the text content of carbon compound concepts based on macro structures and images of chemical representations. The research was conducted towards high school / MA chemistry textbooks using Siregar's macro structure criteria and GKitzia criterion of connectedness with chemical representation The results of the content analysis in the book $A$ and $B$ shows that the content presentation and its scope is not as wide as the content in standard text books. However, the concepts that have been presented are in accordance with the curriculum. Based on the macro structure, the content presentation plot in standard textbooks mostly uses inductive grooves, whereas the deductive grooves are used in book $A$ and book $B$. The text representation of those three books is more leads to symbolic dominance. The result of image representation analysis which is presented in these three books showed that most of the pictures in standard textbooks have met the criteria. Of the three books, more images showing symbolic representations. The core which is contained in the representations of the three books is largely implicit. The representations connectedness of standard textbooks and book $B$ is almost related and connected to text completely. The three books are more dominant, but do not have a description or caption on each image. Multiple linkages that make up the representation in standard text books indicated clearly but less connected.
\end{abstract}

Keywords: textbook, carbon compound, criterion of connectedness with chemical representation.

DOI: https://doi.org/10.15575/jtk.v3i1.2682 


\section{PENDAHULUAN}

Pendidikan memiliki peran penting dalam menunjang kemajuan Bangsa dan Negara. Salah satu peranannya untuk meningkatkan kualitas generasi muda sebagai sumber daya manusia yang unggul dan kompetitif (Takdir, 2012:10). Upaya peningkatan mutu pendidikan dapat ditinjau dari berbagai aspek, seperti peningkatan kualitas tenaga pengajar dan melengkapi sumber belajar yang merupakan sarana dan prasarana pendidikan (Vitriani, 2012:1).

Salah satu sumber belajar adalah bahan ajar yang cukup dan layak (Wahab dkk., 2016:1090). Menurut Hamdani (2011:218), bahan ajar merupakan bahan dasar dalam melaksanakan kegiatan belajar mengajar di kelas, berupa bahan tertulis atau tidak tertulis. Menurut Prastowo (2012:40), bahan ajar tersebut dapat berupa bahan ajar cetak (printed), seperti hand out, buku, modul, Lembar Kerja Siswa (LKS), brosur, leaflet, wallchart, foto/gambar, dan model/maket; bahan ajar dengar, seperti kaset, radio, piringan hitam, dan compact disk audio; bahan ajar audiovisual, seperti video compact disk dan film; bahan ajar interaktif, seperti compact disk interactive. Dari berbagai jenis bahan ajar yang ada, salah satu yang sering digunakan di dalam proses pembelajaran adalah buku teks.

Buku teks merupakan salah satu sumber belajar yang efektif sebagai penunjang proses pembelajaran mandiri, sumber efektif untuk menyajikan isi oleh guru, sebuah sumber ide dan aktivitas, sumber referensi untuk peserta didik, dan sebuah silabus yang merefleksikan pembelajaran yang objektif (Novianto, 2015:7). Di Indonesia, banyak buku teks mata pelajaran yang digunakan untuk pembelajaran, salah satunya yaitu buku teks pelajaran kimia.

Buku teks mempunyai peranan penting bagi siswa di dalam proses pembelajaran kimia (Adisendjaja \& Romlah, 2007:1). Referensi berupa buku teks sangat menunjang peserta didik dalam mengerjakan tugas (Prastowo, 2012:1). Keberadaan buku teks pelajaran kimia di sekolah-sekolah harus memiliki kebenaran isi, penyajian yang sistematis, penggunaan bahasa dan keterbacaan yang baik, dan grafika yang fungsional (Muslimin, 2011:2).

Clifford (dalam Devetak et al., 2013:3) mengungkapkan bahwa informasi mengenai konsep yang ditemukan dalam buku teks tidak selalu akurat. Hal ini menunjukkan bahwa pengetahuan ilmiah dalam buku teks pelajaran yang disajikan secara tidak konsisten akan berdampak negatif pada pemikiran siswa, buku teks yang isi dan penyajiannya kurang sesuai dapat menyebabkan miskonsepsi siswa (Irez dalam Devetak et al., 2013:3).

Miskonsepsi yang terjadi pada penggunaan buku teks kimia salah satunya ketika mempelajari konsep senyawa karbon. Senyawa karbon merupakan salah satu konsep yang termasuk kedalam ilmu kimia. IImu kimia merupakan salah satu cabang ilmu yang mempelajari perubahan materi secara khusus, baik perubahan secara fisika maupun secara kimia (Sunarya, 2000:1). Karakteristik konsep senyawa karbon yaitu cukup sulit dipahami siswa karena konsep senyawa karbon ini banyak menggunakan simbol-simbol kimia yang dikaitkan dengan fenomena yang ada dalam kehidupan sehari-hari. Sehingga materi senyawa karbon termasuk ke dalam jenis konsep abstrak dengan contoh konkret. Materi ajar yang bersifat abstrak perlu pemahaman secara konkret agar mudah diterima oleh siswa (Nurmariza dkk., 2016:1113).

Jhonston (dalam Kern et al., 2010:165), menyatakan karakteristik pelajaran kimia berkaitan dengan tingkat pemikiran multipel representasi kimia diantaranya makroskopik, submikroskopik dan simbolik. Salah satu alasan penting sulitnya siswa dalam memahami materi kimia sangat erat kaitannya dengan multipel representasi kimia (Jhonstone dalam Haryani dkk., 2014:49). Untuk meminimalisir miskonsepsi pada siswa serta melihat kelengkapan beberapa level representasi kimia pada buku teks kimia maka perlu dilakukan analisis.

Berdasarkan hasil survey peneliti terhadap beberapa sekolah di wilayah Bandung Utara, diperoleh dua data buku teks yang paling banyak digunakan, diantaranya buku dengan 
judul Kimia tiga untuk SMA/MA kelas XII karangan Michael Purba dan buku dengan judul yang sama karangan Teguh Pangajuanto. Hal ini pula yang mendasari pemilihan buku teks kimia yang akan dianalisis baik dari segi konten, penyajian, maupun representasi kimia. Buku teks kimia standar yang digunakan dalam penelitian ini adalah buku dengan judul chemistry karangan McMurry \& Fay. Buku tersebut merupakan buku standar yang dipilih sebagai sumber acuan dalam mengembangkan kriteria representasi kimia (GKitzia et al., 2010:14). Kriteria GKitzia tidak hanya melihat dari keberadaan representasi, melainkan dari beberapa aspek keterangan gambar, keterkaitan antara gambar dengan teks, serta aspek keterhubungan dengan representasi lain (Sudrajat dkk., 2016:185).

Penelitian mengenai buku teks pelajaran kimia telah banyak dilakukan sebelumnya, Sugiarti \& Farida (2013) dalam penelitiannya mengenai analisis buku teks konsep kesetimbangan kimia, Sudrajat dkk. (2016) mengenai sel volta, Rahayu (2016) mengenai ikatan kimia, telah banyak memberikan informasi bahwa buku teks mata pelajaran kimia yang beredar di berbagai sekolah belum sepenuhnya mencakup semua konsep yang terdapat pada konten buku teks standar.

\section{METODE PENELITIAN}

Metode penelitian yang digunakan untuk menjabarkan fenomena-fenomena dalam penelitian yaitu metode penelitian deskriptif kualitatif analisis wacana. Penelitian ini melakukan analisis terhadap konten-konten yang terdapat pada buku teks dengan cara menganalisis dan menguraikan setiap indikator konten teks tersebut berdasarkan kepada representasi kimia.

Objek pada penelitian ini yaitu tiga buah buku teks kimia yang akan dianalisis. Buku pertama yang akan dianalisis adalah buku teks kimia standar karangan John E. Mc Murry \& Robert C. Fay yaitu Chemistry Sixth Edition tahun 2012. Dua buah buku lainnya merupakan buku teks kimia SMA/MA kurikulum 2006 dan kurikulum 2013 pegangan siswa kelas XII yaitu buku kimia karangan Michael Purba tahun
2007 yang kemudian disebut sebagai buku $A$, dan buku kimia karangan Unggul Sudarmo tahun 2013 yang kemudian disebut sebagai buku B. Kedua buku ini dipilih berdasarkan hasil studi pendahuluan pada penggunaan buku teks kimia di SMA/MA di wilayah Bandung Utara.

Pada penelitian kali ini terdapat tiga tahap langkah utama, yaitu: 1) Tahap persiapan, pada tahap ini peneliti melakukan observasi ke berbagai sekolah di wilayah Bandung, pengkajian literatur, perumusan masalah dan tujuan penelitian, menganalisis standar isi serta menganalisis konsep senyawa karbon; 2) Tahap pelaksanaan, meliputi pengumpulan data, penyusunan instrumen penelitian serta analisis buku teks; 3) Tahap analisis data dan penarikan kesimpulan, pada tahap ini data yang telah dikumpulkan dianalisis dan diinterpretasikan sehingga pada akhirnya dapat ditarik sebuah kesimpulan.

Instrumen yang digunakan dalam penelitian ini diantaranya struktur makro wacana, tabel analisis konten materi, tabel analisis kategori representasi, dan angket studi. Kriteria yang dihasilkan dari setiap representasi disajikan dalam bentuk presentase dengan rumus:

$$
\% \text { ktiteria }=\frac{\text { jumlah kriteria representasi }}{\text { jumlah total representasi }} \times 100 \%
$$

\section{HASIL DAN PEMBAHASAN}

\subsection{Struktur Umum Penyajian Konten}

Analisis konten dapat dilakukan dengan mengklasifikasikan kata-kata dari teks kedalam kategori yang lebih kecil (Wang dalam Devetak et al., 2013: 7). Struktur umum, terdiri dari informasi umum seperti jumlah halaman, bab, panjang bab, persentase tekstual dan konsep bergambar pada bab khusus dan seluruh buku teks (Devetak et al., 2013: 6).

Konsep Senyawa Karbon pada buku teks standar terdapat pada chapter 23 dengan judul Organic and Biological Chemistry dimulai dari halaman 908 sampai 932. Konsep senyawa karbon pada buku ini terdiri dari delapan subbab. Konsep yang dianalisis secara

Jurnal Tadris Kimiya 3, 1 (Juni 2018): 83-93 
berurutan yaitu mengenai molekul organik dan strukturnya: alkana; kelompok dari senyawa organic; gugus fungsi; tata nama senyawa organik; senyawa organik tak jenuh: alkena dan alkuna; senyawa organik siklik; senyawa aromatik; alkohol, eter dan amina; dan senyawa karbonil.

Pada buku A, konsep senyawa karbon terdapat pada bab tujuh dengan judul senyawa turunan alkana, penjelasan dimulai dari halaman 210 sampai 246. Bab senyawa turunan alkana pada buku ini terdiri dari lima Subbab, yaitu: a) gugus fungsi, meliputi pengertian gugus fungsi beserta contohnya; b) alkohol dan eter, meliputi keisomeran, tata nama alkohol dan eter, jenis-jenis alkohol, sifat alkohol dan eter, pembuatan alkohol dan eter, serta kegunaan alkohol dan eter; c) aldehida dan keton, meliputi keisomeran, tata nama aldehida dan keton, sifat aldehida dan keton, pembuatan (sintesis) aldehida dan keton, serta kegunaan aldehida dan keton; d) asam karboksilat dan ester, meliputi keisomeran, tata nama, sifat, pembuatan, serta kegunaan asam karboksilat dan ester.

Pada buku B, konsep senyawa karbon terdapat pada bab empat dengan judul senyawa turunan alkana, konsep dimulai dari halaman 165 sampai 204. Buku ini terdiri dari lima subbab. Konsep yang dianalisis secara berurutan yaitu gugus fungsi, tata nama senyawa turunan alkana, keisomeran, reaksireaksi senyawa karbon, serta kegunaan dan dampak beberapa senyawa turunan alkana.

\subsection{Hubungan dengan Kurikulum}

Analisis konten dapat dilakukan dengan mengidentifikasi konsep-konsep kunci dan hubungan yang sesuai dengan tujuan pembelajaran yang sesuai dengan kurikulum nasional (Devetak et al., 2013: 6-7). Tujuan pembelajaran yang akan dicapai pada buku teks dapat dilihat dari konsep-konsep yang disajikan di dalamnya.

Berdasarkan tujuan dari ketiga buku teks tersebut, secara umum konsep-konsep yang disajikan oleh setiap buku memiliki keterkaitan atau sesuai dengan kompetensi dasar (KD) yang terdapat pada kurikulum.

\subsection{Perbandingan Konten Buku A dan Buku B Terhadap Buku Standar}

Langkah awal dalam menganalisis adalah dengan menyusun konsep kunci berdasarkan teks standar dengan kurikulum. Konsep kunci yang telah disusun akan menjadi acuan dan pembanding dalam analisis.

Konsep kunci yang menjadi acuan adalah konsep kunci yang tertera pada buku standar. Hasil yang diperoleh menunjukkan kelengkapan konsep yang dibahas pada masing-masing buku teks.

Berdasarkan hasil tersebut, dapat dilihat bahwa terdapat beberapa konsep yang tidak dibahas pada buku A dan buku B jika dibandingkan dengan buku standar. Adapun kesamaan pembahasan konsep, terdapat beberapa konsep yang berbeda dalam penyebutan istilah untuk konsep kunci. Misalnya konsep mengenai disosiasi asam karboksilat di air, pada buku A konsep kuncinya disebutkan dengan reaksi ionisasi asam karboksilat. Keduanya sama-sama membahas konsep yang sama, hanya berbeda dalam penyebutan istilah konsep kunci. Mengacu kurikulum yang berlaku, terdapat perbedaan antara buku standar dengan buku $A$ dan buku B. Konsep kunci yang tidak sesuai dengan kurikulum tidak dibahas seperti yang tertera pada tabel diatas.

\subsection{Hasil Analisis Representasi Gambar Buku Teks Standar, Buku A, dan Buku B}

Menurut Cook (dalam Devetak et al., 2013:5) representasi merupakan dasar dari pembelajaran visual. Representasi yang terdapat pada buku teks meliputi gambar, foto, persamaan reaksi, struktur senyawa, dan tabel. Analisis dilakukan dengan mengacu pada representasi kimia kriteria GKitzia. 
Tabel 1. Representasi yang Paling Banyak Muncul pada Ketiga Buku

\begin{tabular}{|c|c|c|c|c|}
\hline \multicolumn{2}{|c|}{ Buku } & Standar & Buku A & Buku B \\
\hline \multirow{5}{*}{ 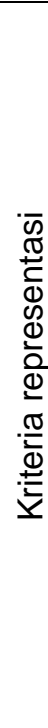 } & C1 & $\begin{array}{l}\text { Simbolik } \\
63,3 \%\end{array}$ & $\begin{array}{l}\text { Simbolik } \\
63,3 \%\end{array}$ & $\begin{array}{l}\text { Simbolik } \\
99 \%\end{array}$ \\
\hline & $\mathrm{C2}$ & $\begin{array}{l}\text { Implisit } \\
62 \%\end{array}$ & $\begin{array}{l}\text { Implisit } \\
74,44 \%\end{array}$ & $\begin{array}{l}\text { Implisit } \\
47 \%\end{array}$ \\
\hline & C3 & $\begin{array}{l}\text { Sepenuhny } \\
\text { a terkait } \\
\text { dan tidak } \\
\text { terhubung } \\
38 \%\end{array}$ & $\begin{array}{l}\text { Sepenuhny } \\
\text { a terkait } \\
\text { dan tidak } \\
\text { terhubung } \\
80 \%\end{array}$ & $\begin{array}{l}\text { Sepenuh } \\
\text { nya } \\
\text { terkait } \\
\text { dan tidak } \\
\text { terhubun } \\
\mathrm{g} \\
31 \%\end{array}$ \\
\hline & C4 & $\begin{array}{l}\text { Tidak } \\
\text { memiliki } \\
\text { caption } \\
63,3 \%\end{array}$ & $\begin{array}{l}\text { Tidak } \\
\text { memiliki } \\
\text { caption } \\
83,33 \%\end{array}$ & $\begin{array}{l}\text { Tidak } \\
\text { memiliki } \\
\text { caption } \\
71 \%\end{array}$ \\
\hline & C5 & $\begin{array}{l}\text { Kurang } \\
\text { terhubung } \\
82,6 \%\end{array}$ & - & - \\
\hline
\end{tabular}

\subsection{Pembahasan Analisis Konten Teks dan Representasi Gambar}

\subsubsection{Pembahasan Analisis Konten Buku Teks Standar, Buku A dan Buku B}

Tarigan dan Tarigan (dalam Toharudin dkk., 2011:190) mendeskripsikan buku teks sebagai berikut:

1. Berbentuk buku yang peruntukannya bagi peserta didik pada jenjang tertentu.

2. Berkaitan dengan bidang studi tertentu serta disusun oleh para ahli yang mumpuni di bidangnya masing-masing.

3. Merupakan buku standar yang dijadikan acuan, berkualitas, dan pengesahannya dilakukan oleh badan yang berwenang.

4. Penulisannya ditujukan pada instruksional tertentu untuk memfasilitasi suatu program pengajaran pada suatu jenjang pendidikan.

Buku teks yang dijadikan acuan oleh guru atau yang diperuntukkan untuk peserta didik harus memenuhi standar isi berdasarkan kurikulum yang berlaku. Alur buku dalam menyajikan konten dapat dilihat salah satunya dari struktur makro. Menurut Siregar (dalam Vitriani, 2012:20) struktur makro merupakan struktur yang diturunkan dari pemetaan proposisi berdasarkan dimensi progresi dan dimensi elaborasi dari proposisi membentuk suatu wacana. Proposisi merupakan unit dasar dari suatu informasi (Vitriani, 2012:20).

Berdasarkan struktur makro buku teks standar, konsep senyawa karbon dapat dilihat dari dimensi progresi yang diulurkan dari atas ke bawah, dan dimensi elaborasi dari kiri ke kanan. Dimensi progresi pada proposisi makro terdapat tujuh konsep yaitu molekul organik dan strukturnya: alkana; kelompok dari senyawa organik: gugus fungsi; tata nama senyawa organik; senyawa organik tak jenuh: alkena dan alkuna; senyawa organik siklik; senyawa aromatik; alkohol, eter dan amina; dan senyawa karbonil. Sedangkan proposisi mikro dapat dilihat dibawah proposisi makronya.

Berdasarkan dimensi progresi dan elaborasi tersebut, ketepatan dan kejelasan konsep senyawa pada buku teks standar disajikan dengan baik dan terperinci serta memiliki keterhubungan yang jelas antara satu unit ke unit lainnya.

Penyajian pada konsep yang pertama yaitu senyawa organik dan strukturnya: alkana dimulai dengan jenis ikatan karbon pada alkana sampai pada penentuan isomer pada alkana, yang sebelumnya dibahas terlebih dahulu mengenai kimia organik dan biokimia, pengertian dan peranan kimia organik, sampai pada kekhasan atom karbon. Dengan demikian, konsep senyawa karbon ini menggunakan alur penyajian induktif.

Menurut Devetak et al. (2013:6), kriteria buku sains yang baik adalah yang memiliki alur penyajian induktif yaitu dari umum ke khusus. Begitupun dengan konsep lain yang disajikan juga memiliki alur induktif.

Keterampilan yang muncul dari setiap konten konsep yang dijelaskan lebih bervariasi dimulai dari mendefinisikan, mencontohkan, menjelaskan, menyebutkan, menentukan, membedakan, hingga menggambarkan. Bagian akhir pembahasan selalu diberikan latihan soal, dan untuk beberapa pembahasan dicantumkan juga contoh soal. Contoh soal dan latihan soal yang diberikan hanya satu sampai dua soal yang dapat mewakili konsep

Jurnal Tadris Kimiya 3, 1 (Juni 2018): 83-93 
yang dijelaskan. Namun, pada contoh soal dilengkapi dengan strategi dan solusi untuk menjawab soal serta cara untuk mengecek jawaban.

Struktur makro pada buku A dan buku B juga disajikan dengan alur induktif. Pada buku $A$, sebagai contoh pada subbab alkohol dan eter, dimulai dengan menjelaskan keisomeran pada alkohol dan eter, tata nama alkohol dan eter, sifat alkohol dan eter, pembuatan alkohol dan eter, sampai pada kegunaannya dalam kehidupan sehari-hari. Begitupun pada subbab lainnya juga disajikan dengan alur induktif.

Pada buku B, sebagai contoh pada subbab reaksi-reaksi senyawa karbon, dimulai dari bagian umum terlebih dahulu yaitu jenis-jenis reaksi yang dapat terjadi pada senyawa karbon, sampai pada reaksi yang terjadi pada masing-masing senyawa karbon (alkohol, eter, aldehid, keton, asam karboksilat, ester dan haloalkana). Begitupun pada subbab lainnya juga disajikan dengan alur induktif.

\subsubsection{Pembahasan Analisis Representasi Buku Standar, Buku A, dan Buku B}

\subsubsection{Ananlisis Representasi Teks Buku Standar, Buku A, dan Buku B}

GKitzia et al. (2010:1), menyatakan bahwa setiap fenomena kimia memiliki tiga aspek representasi: makro (apa yang diamati); submikro (apa yang terjadi pada tingkat molekuler); dan aspek simbolik (bagaimana fenomena dilambangkan). Representasi kimia digambarkan seperti sebuah segitiga, ketiganya saling berkesinambungan meskipun memiliki peranan yang berbeda. Makroskopik termasuk kedalam konsep konkret sedangkan submikroskopik dan simbolik merupakan konsep abstrak (Johnstone dalam TockusRappoport, 2008:13). Kalimat yang baik adalah kalimat yang memuat tiga representasi tersebut. Satu fenomena dijelaskan dari berbagai representasi untuk memudahkan pembaca.

Dari ketiga aspek representasi, yang paling banyak muncul dalam teks pada buku standar, buku A dan buku B adalah simbolik dan submikroskopik. Dalam setiap kalimat yang dianalisis, ada yang hanya memuat simbolik saja, ada yang hanya memuat makroskopik saja, ada yang memuat submikroskopik saja, dan ada yang memuat lebih dari satu representasi, misalnya simbolik dan submikroskopik. Konsep senyawa karbon banyak memuat fenomena yang dilambangkan dengan simbol kimia. Hampir keseluruhan isi dibahas dan direpresentasikan dengan simbol.

Pada buku standar, representasi yang disajikan pada teks hampir seluruhnya didukung oleh adanya gambar. Sedangkan pada buku A dan buku B tidak demikian. Penyajian konten yang terdapat pada ketiga buku (terutama buku standar dan buku B) cukup baik, setiap konsep selalu dikaitkan dengan fenomena nyata yang ada dalam kehidupan sehari-hari. Ahtineva (2005:7) menyatakan bahwa kriteria buku teks sains yang baik yaitu yang menghubungkan konsep dengan kehidupan faktual.

Pada buku standar, salah satu contohnya ketika menjelaskan konsep ester. Selain terdapat penjelasan mengenai pengertian, tata nama, reaksi, dan sifat, terdapat juga penjelasan mengenai aplikasinya dalam kehidupan sehari-hari. Ester merupakan golongan senyawa yang banyak diaplikasikan dalam pembuatan essen buah-buahan. Pada buku teks, buah yang dicontohkan yaitu pada pisang. Penjelasan mengenai essen pisang disajikan dengan teks dalam kalimat yang jelas serta didukung oleh adanya representasi gambar.

Pada buku A, salah satu contohnya ketika menjelaskan konsep asam karboksilat. Selain terdapat penjelasan mengenai pengertian, tata nama, reaksi, sifat dan pembuatan, terdapat juga penjelasan mengenai kegunaan dan aplikasi asam karboksilat dalam kehidupan sehari-hari. Salah satu contoh senyawa asam karboksilat yaitu asam format. Asam format merupakan senyawa yang dihasilkan oleh semut. Pada buku teks, disajikan fenomena terkait asam format yang didukung dengan adanya representasi gambar.

Jurnal Tadris Kimiya 3, 1 (Juni 2018): 83-93 
Pada buku B, salah satu contohnya ketika menjelaskan konsep keisomeran pada senyawa turunan alkana. Selain dijelaskan mengenai isomer apa saja yang mungkin terdapat pada konsep, dijelaskan juga mengenai salah satu kasus yang berkaitan dengan isomer, yaitu kasus talidomit yang merupakan contoh untuk menggambarkan pengaruh konfigurasi terhadap sifat zat.

\subsubsection{Analisis Representasi Gambar Buku Standar, Buku A, dan Buku B}

Representasi yang paling banyak terdapat pada buku B yaitu 100 representasi. Sedangkan pada buku standar terdapat 79 representasi, dan pada buku $A$ terdapat 90 representasi, yang terdiri dari gambar, tabel, dan rumus kimia atau persamaan reaksi. Buku B memiliki jumlah representasi terbanyak dikarenakan terdapat banyak sekali representasi dalam bentuk simbol (simbolik). Representasi gambar, rumus atau persamaan kimia, dan tabel pada buku standar sangat beragam. Terdapat empat jenis representasi gambar (C1) yang muncul dalam buku ini meliputi: 2,53\% makroskopik, 5\% submikroskopik, 63,3\% simbolik, 29,11\% multipel.

Interpretasi surface feature (C2) yang terdapat dalam buku teks standar meliputi; $62 \%$ implisit dan 16,46\% eksplisit. Keterkaitan gambar dengan teks (C3) pada buku standar meliputi: $12,66 \%$ sepenuhnya terkait dan terhubung, $38 \%$ sepenuhnya terkait dan tidak terhubung, $3,8 \%$ sebagian terkait dan terhubung, serta $24 \%$ sebagian terkait dan tidak terhubung. Ada/tidaknya keterangan gambar (C4) pada buku teks standar meliputi: 11,4\% memiliki caption yang sesuai, $1,26 \%$ memiliki caption yang kurang sesuai dan $63,3 \%$ tidak memiliki caption. Dan untuk derajat keterhubungan antara level-level representasi (C5) pada buku standar meliputi: 17,4\% cukup terhubung, dan $82,6 \%$ kurang terhubung.

Sementara itu, representasi gambar, rumus atau persamaan kimia, dan tabel pada buku $A$ terdiri dari: C1 (Jenis Representasi): 3,33\% makroskopik, 4,44\% submikroskopik, dan 96,7\% simbolik; C2 (Interpretasi Surface Feature): $74,44 \%$ implisit dan 18,9\% eksplisit;
C3 (Keterkaitan Gambar dengan Teks): 4,44\% sepenuhnya terkait dan tehubung, $80 \%$ sepenuhnya terkait dan tidak terhubung, serta $2,22 \%$ sebagian terkait dan tidak terhubung. C4 (Ada/Tidaknya Keterangan Gambar): $3,33 \%$ memiliki caption yang sesuai, dan $83,33 \%$ tidak memiliki caption. Pada buku A tidak terdapat representasi dengan jenis multipel, sehingga tidak dijelaskan mengenai derajat keterhubungan gambar.

Sedangkan representasi gambar, rumus atau persamaan kimia, dan tabel pada buku B terdiri dari: C1 (Jenis Representasi): 4\% makroskopik, dan 96\% simbolik; C2 (Interpretasi Surface Feature): 47\% implisit dan 33\% eksplisit; C3 (Keterkaitan Gambar dengan Teks): $10 \%$ sepenuhnya terkait dan tehubung, $31 \%$ sepenuhnya terkait dan tidak terhubung, $24 \%$ sebagian terkait dan terhubung, serta $17 \%$ sebagian terkait dan tidak terhubung. C4 (Ada/Tidaknya Keterangan Gambar): 9\% memiliki caption yang sesuai, $1,26 \%$ memiliki caption yang kurang sesuai dan $71 \%$ tidak memiliki caption. Pada buku B tidak terdapat representasi multipel.

Menurut GKitzia et al., (2010:4), terdapat beberapa kriteria representasi gambar yang baik. Pada kriteria (C1) jenis representasi gambar yang ideal adalah multipel, gambar menyajikan lebih dari satu representasi. Pada buku standar tedapat 23 gambar dengan jenis multipel representasi. Dari 23 multipel representasi yang terdapat pada buku standar, paling banyak terdapat multipel representasi yang merupakan gabungan dari representasi jenis submikroskopik. Sedangkan pada buku A dan buku B tidak terdapat satupun representasi dengan jenis multipel representasi.

Dari ketiga buku ini, hanya buku standar yang memiliki representasi jenis submikroskopik. Selain itu, representasi yang paling banyak muncul dari ketiga buku adalah representasi simbolik. Hal tersebut dikarenakan jenis konsep senyawa karbon banyak yang berupa konsep yang menyatakan simbol.

Representasi gambar yang baik pada buku teks menurut GKitzia et al. (2010:9) pada kriteria C2 yaitu interpretasi surface feature harus bersifat eksplisit, setiap fitur atau komponen yang penting yang terdapat pada 
gambar harus disebutkan dengan jelas maknanya. Pada buku standar sebagian besar makna yang terlihat dari setiap representasi termasuk kategori implisit, karena pada buku standar banyak penggambaran model molekul (model bola dan tongkat) senyawa, namun setiap bola tidak diberi keterangan termasuk unsur apa, hanya diberi warna yang berbeda.

Keterangan dari fitur-fitur penting disajikan di awal sebelum menampilkan gambar/representasi terkait atau berada pada keterangan gambar/caption. Begitupun dengan buku $A$ dan buku $B$, fitur yang disajikan sebagian besar bersifat implisit. Namun, pada buku tersebut sebagian besar makna fitur yang tidak tidak ditampilkan tidak pula dijelaskan pada teks atau pada keterangan gambar, seperti pada buku standar.

Representasi gambar yang baik pada buku teks menurut GKitzia et al. (2010:10) pada kriteria C3 yaitu keterkaitan antara gambar dengan teks harus sepenuhnya terkait dan terhubung. Berdasarkan hasil analisis C3 pada ketiga buku, sebagian besar gambar terhubung dan terkait sepenuhnya dengan teks, kemudian beberapa gambar terkait sepenuhnya tapi tidak terhubung dengan teks, dan sangat sedikit gambar terhubung dan terkait sebagian dengan teks. Ketiga buku tersebut memiliki kriteria C3 yang baik karena menurut Devetak et al. (2013:5) buku teks yang baik merupakan buku yang mempunyai hubungan yang tepat antara penjelasan tekstual dan materi bergambar yang disajikan. Representasi gambar yang baik pada buku teks menurut GKitzia et al. (2010:11) pada kriteria C4 yaitu memiliki caption yang sesuai. Berdasarkan hasil analisis C4 pada ketiga buku, sebagian besar gambar yang disajikan tidak memiliki caption dan sisanya memiliki caption yang sesuai, representasi yang tidak memiliki caption merupakan representasi berupa rumus struktur senyawa dan persamaan reaksi, karena penjelasannya terdapat pada penjelasan/teks yang disajikan.

Representasi gambar yang baik pada buku teks menurut GKitzia et al. (2010:11) pada kriteria C5 yaitu cukup terhubung. Kriteria ini khusus untuk representasi dengan jenis multipel. Berdasarkan hasil analisis C5 pada buku standar sebagian besar multipel representasi yang disajikan kurang terhubung karena banyak representasi berupa struktur senyawa atau bentuk makroskopik suatu representasi yang dilengkapi dengan model molekulnya namun diletakkan secara paralel. Sehingga, meskipun terdapat kesetaraan antara level-level representasi, hubungan antara elemennya tidak begitu jelas.

\section{KESIMPULAN}

Pada buku A dan buku B menyajikan hampir semua konsep kunci yang dijelaskan oleh buku teks standar. Penyajian konten dan cakupannya tidak seluas dan sedalam konten pada buku teks standar serta kurang mengaitkan dengan fenomena dalam kehidupan sehari-hari. Namun konsep-konsep yang disajikan sudah sesuai dengan kurikulum. Berdasarkan struktur makro, alur penyajian konten pada buku teks standar sebagian besar menggunakan alur induktif, sedangkan pada buku A dan buku B menggunakan alur deduktif. Representasi teks dari ketiga buku lebih dominan menampilkan representasi simbolik. Pada ketiga buku dilengkapi dengan contoh soal dan latihan soal untuk setiap konsep yang dibahas. Bahkan latihan soal yang disajikan pada buku A dan buku B cukup banyak dan bervariasi.

Hasil analisis representasi gambar yang disajikan buku standar, buku A dan buku B menunjukkan sebagian besar gambar yang disajikan pada buku teks standar sudah memenuhi kriteria, namun pada buku $A$ dan buku B belum memenuhi kriteria standar. Dari ketiga buku, lebih banyak menampilkan gambar dengan representasi simbolik. Makna yang terkandung dalam representasi dari ketiga buku sebagian besar bersifat implisit. Keterhubungan representasi dari buku teks standar dan buku B hampir sepenuhnya terkait dan terhubung dengan teks, sedangkan pada buku $A$ keterhubungan dengan teks hampir sepenuhnya terkait tetapi tidak mengandung kalimat penghubung. Ketiga buku lebih dominan tidak memiliki keterangan/caption dari setiap gambar. Keterhubungan yang menyusun representasi multipel pada buku teks standar ditunjukan dengan jelas tetapi kurang terhubung. Pada buku $A$ dan buku $B$ 
tidak dapat ditunjukan karena tidak

mengandung representasi multipel.

Berdasarkan uraian tersebut dapat disimpulkan penyajian gambar pada buku $A$ dan buku $B$ belum memenuhi kriteria representasi yang baik yang ditetapkan oleh Gkitzia. 


\section{DAFTAR PUSTAKA}

Adisendjaja dan Romlah. (2007). Analisis Buku Ajar Sains Berdasarkan Literasi IImiah Sebagai Dasar Untuk Memilih Buku Ajar Sains (Biologi). Jurnal Pendidikan , 1, 18.

Ahtineva, A. (2005). Textbook Analysis in the Service. Nature, 10, 25-33.

Devetak, I dan Vogrinc, J. (2013). Critical Analysis of Science Textbook. New York London: Springer.

Gkitzia, V., Salta, K., dan Tzougraki, C. (2010). Development and Application Of Suitable Criteria for The Evaluation of Chemical Representations in School Textbooks. Chemistry Education Research and Practice, 12, 5-12.

Hamdani. (2011). Strategi Belajar Mengajar. Bandung: CV Pustaka Setia.

Haryani, S., Prasetya, A. T., dan Saptarini. (2014). Identifikasi Materi Kimia SMA Sulit Menurut Pandangan Guru dan Calon Guru Kimia. Seminar Kimia dan Pendidikan Kimia, 6, 43-52.

Kern, A. L., Wood, N. B., Roehrig, G. H., \& Nyachwaya, J. (2010). A Qualitative Report Of The Ways High School Chemistry Student Attempt To Represent A Chemical Reaction At The Atomic/molecular Level. Chemistry Education Research and Practice, 11, 165-172.

Muslimin. (2011). Analisis Buku Teks Bahasa Indonesia Untuk SMP Kelas IX Dengan Pendekatan Tematik. Jurnal Bahasa, Sastra dan Budaya , 1.

Novianto, A. (2015). Analisis Buku Teks Muatan Tematik Integratif, Scientific
Approach, dan Authentic Assesment Sekolah Dasar. Jurnal Kependidikan, 1.

Nurmariza, Ibrahim dan Widodo. (2016). Pengembangan Bahan Ajar Berbasis Aktivitas Dengan Media Cd Interaktif pada Materi Indera Pendengaran dan Sistem Sonar. Jurnal Pendidikan, 6, 1113-1122.

Prastowo, A. (2012). Panduan Kreatif Membuat Bahan Ajar Inovatif. Yogyakarta: Diva Press.

Rahayu, Ratna Puri (2016). Analisis Bahan Ajar Ikatan Kimia pada Buku Teks SMA Berdasarkan Kriteria Keterhubungan Representasi Kimia. Diploma Thesis. Bandung: UIN Sunan Gunung Djati Bandung.

Sudrajat, Devi P., Farida, Ida, dan Pitasari, Ratih (2016). Analisis Bahan Ajar Sel Volta pada Buku Teks Kimia SMA/MA Berdasarkan Kriteria Keterhubungan Representasi Kimia. Prosiding Simposium Nasional Inovasi dan Pembelajaran Sains 2016. 184-181.

Sugiarti, Rita dan Farida, Ida (2013). Analisis Buku Teks Kimia pada Konsep Kesetimbangan Kimia ditinjau dari Kriteria Representasi. Prosiding Simposium Nasional Inovasi dan Pembelajaran Sains 2013, 216-219.

Sunarya, Y. (2000). Kimia Dasar I: Prinsipprinsip Kimia Terkini. Jakarta: Alkemi Grafisindo Press.

Takdir M.I. (2012). Pembelajaran Discovery Strategy \& Mental Vocational Skill. Jogjakarta: Diva Press

Tockus-Rappoport, L. (2008). Computer Simulations as a Bridge between 
Different Representation Levels of Scientific Concepts. Dissertation. Hebwer University.

Toharudin, U., Hendrawati, S., dan Rustaman Andrian. (2011). Membangun Literasi Sains Peserta Didik. Bandung: Humaniora.

Vitriani, I. R. (2012). Analisis Wacana Sistem
Eksresi Pada Buku Pelajaran IPA Terpadu SMP dan Buku Pelajaran Biologi SMA.. Tesis. Bandung: SPS UPI. Tidak Diterbitkan.

Wahab, Wasis dan Indana. (2016). Pengembangan Bahan Ajar Komik pada Materi Sistem Transportasi Makhluk Hidup Untuk Menumbuhkan Minat Baca dan Meningkatkan Hasil Belajar. Jurnal Pendidikan, 6, 1090-1099. 